\title{
UNDERSTANDING YOUNGER TOURIST' INTENTION TOWARD ENVIRONMENTALLY RESPONSIBLE BEHAVIOR
}

\author{
Rakotoarisoa Maminirina FENITRA \\ Universitas Airlangga, Department of Doctorate Management Science, Surabaya Indonesia, e-mail: maminirina.fenitra.r-2018@ feb.unair.ac.id,
}

Handriana TANTI*

Universitas Airlangga, Department of Doctorate Management Science, Surabaya Indonesia, e-mail: tanti.handriana@ feb.unair.ac.id,

Candra Premananto GANCAR

Universitas Airlangga, Department of Doctorate Management Science, Surabaya Indonesia, e-mail: gancar-c-p@ feb.unair.ac.id,

Usman INDRIANAWATI

Universitas Airlangga, Department of Doctorate Management Science, Surabaya Indonesia, e-mail: indrianawati-u@feb.unair.ac.id

Citation: Fenitra, R.M., Tanti, H., Gancar, C.P, \& Indrianawati, U. (2021). UNDERSTANDING YOUNGER TOURIST' INTENTION TOWARD ENVIRONMENTALLY RESPONSIBLE BEHAVIOR. GeoJournal of Tourism and Geosites, 36(2spl), 646-653. https://doi.org/10.30892/gtg.362spl12-694

\begin{abstract}
Despite the significant contribution of the tourist growth to the economics, besides the concern of its impact on the environment has gained much attention. This integrated green image in the theory of planned behavior to determine the factor influencing Younger tourist environmentally responsible intention behavior particularly recycling behavior intention. The study identified the factors influencing tourist environmentally responsible behavior within the lens of the theory Of Planned Beha vior (TPB). The framework was tested with regression analysis with data collected from 229 younger traveler visiting in Bali, Indonesia. The result showed that environmental attitude, subjective norm have a positive impact on younger tourist environmentally responsible intention (recycling intention). Whereas, perceived behavior control does not influence intention. Further, Destination Green Image has a positive impact on environmental attitude. This finding provide an additional knowledge and understanding to the existing body literature of tourist behavior particularly in context of tourism environmentally responsible behavior. Practical and theoretical implication for sustainable tourism are proposed on this study.
\end{abstract}

Key words: Recycling, sustainable tourism, younger, Indonesia, intention behavior, environmentally responsible behavior, tourist behavior

$* * * * * *$

\section{INTRODUCTION}

The increasing demand in tourism industry has a potential positive contribution to the global economic (Han et al., 2016; Janmaimool and Khajohnmanee, 2019). The tourism industry has the fastest market growth, and this growth brings an enormous benefit to the tourist destinations in any sides such as improving the economics, socio-cultural and environment (Chia et al., 2020). However, this rapid transformation makes the tourism industry more vulnerable cause by the human activity; consumption pattern and human mobility. Despite the fact that tourism activities have positive contribution also bring about enormous challenges to the local communities local environment (Landon et al., 2018; Biswas et al., 2000).

Maintaining the environmental quality is one way to foster a prosperous sustainable tourism industry. Although individuals are aware of the consequence of their behavior, consumption pattern, the tourism destination is often facing the challenges such as a waste generation andpollution. Some studies indicated that tourist post-consumption behavior brings a major negative impact to destination environment (Nunkoo et al., 2019; Zhang et al., 2019a; Zuo and Huang, 2019; Patwary et al., 2020). This is due to the fact that people are less environmentally friendly when traveling (He et al., 2018). Budeanu, (2007) noted only small percentage of tourism engaged in sustainable behavior when traveling.

With reference to Arbulu et al., (2017) in study related to the impact of tourist, they noted that the increasing number of tourists on arrival would increase the waste generation flow. Yet, during the pandemic Covid-2019, this issue has decline due to some regulation and restriction, and the environmental quality improves. Yet, understanding the tourist behavior and what drives that behavior is needed in order to tackle these issues in a long run.

The study focused on environmentally responsible behavior (ERB) has gained much attention from various fields and become a distinguished topic interest in tourism research (Xu et al., 2019; Han et al., 2016; Kiatkawsin et al., 2020; Najib et al., 2020). TERB refers to the tourist's commitment to contribute in minimizing the environmental impact caused by the consumption pattern (Kiatkawsin et al., 2020). Tourist environmentally responsible behavior (TERB) have been conceptualized differently depending on the context. TERB is referred to by different scholars as the behavior related tourist concerned about the environmental problem namely littering behavior, environmentally friendly behavior and so on (Cheng

\footnotetext{
* Corresponding author
} 
and $\mathrm{Wu}, 2015$; Han et al., 2016; Kim et al., 2017; Xu et al., 2019). In this work we conceptualized tourist environmentally responsible intention behavior (TERIB) as the tourist's intended behavior to recycle their waste when traveling (Nindyati, 2015; He et al., 2018). Studying TREB is crucial in promoting sustainable tourism in tourist destination (Lee and Jan, 2015; Cheng and $\mathrm{Wu}, 2015$; Pan and Liu, 2018; He et al., 2018). Prior scholars argued that TPB is one of the most relevant theory to explain the TERB (Wang et al., 2019). Theory of Planned Behavior (attitude, intention behavior, subjective norm, and perceived behavior control) is considered as a suitable theory to predict individuals' intention to engage in sustainable behavior (Han et al., 2016; Han et al., 2018; Landon et al., 2018). The present study aims to explore younger tourist environmentally responsible intention behavior using extended Theory of Planned behavior. This model integrated destination Image in the lens of theory of planned behavior. Prior urged that tourists are more likely to engage in environmentally friendly way in tourist destination area that is perceived as a green destination (Pan and Liu, 2018; Ashraf et al., 2019).

Han et al., (2018) explained that green destination image can elicit one's behavior to support a green behavior. Hence, it's coherent to assume that green image can influence TERIB. However, to the best of our knowledge there is little done in addressing the question on Does destination green image influence the TERIB. This propose to identify the determinant of this particular using extended theory of planned behavior, among younger tourist in Bali, Indonesia. The objectives are (1) to determine the relationship of environmental attitude, subjective norm, perceived behavior control and green image on ERIB; (2) to determine the mediating role attitude in the relationship between green image and younger tourist environmentally responsible intention behavior (YTERIB). The findings expected to determine the factor influencing young tourist intention behavior to expand to the literature of TERB. In respect to provide an additional understanding for managerial implication and policy implication in shaping a strategy to promote sustainable behavior (recycling) in tourism destination.

\section{TPB and Tourist Environmentally Responsible Intention Behavior}

The theory of planned behavior (TPB) (Ajzen, 1991) is one of the prevalent theory to determine ones' behavior. TPB suggested that behavior is determined by intention behavior (Ajzen, 1991). Intention refers to the tendency and probability of an individual to perform a certain behavior in the future. Ajzen (1991) advocated three elements that determined intention namely attitude, subjective norm and perceived behavior control. This study expended TPB with destination green image to explain the YTERIB particular in recycling. Past scholars have argued that TPB is the fundamental theory to examine proenvironmental behavior related (Han et al., 2018; Hu et al., 2018; Kumar, 2019 Clark et al., 2019; Tweneboah-Koduah et al., 2019). TERB refers to the contribution of tourist to minimize the negative impact and protect the environment through their activity during their traveling. TERIB refers to the intended behavior of tourist to engage in environmentally friendly when traveling, including recycling, choosing eco-tourism destination (Zhang et al., 2019), littering (Arrow et al., 2017; Hu et al., 2018), choosing eco-friendly and green transportation and actives, energy and conservation, ecological (Chueng, 2016), energy conservation (Lee and Jan, 2015; Han et al., 2016; Fang, 2017; Kiatkawsin and Han, 2017; He et al., 2018; Abdullah et al., 2019; Kim and Stepchenkova, 2019; Su et al., 2019; Janmaimool and Khajohnmanee, 2019; Xu et al., 2019; Zhou et al., 2020).

\section{Environmental Attitude and Tourist Environmentally Responsible Intention Behavior}

Attitude refers to the psychological judgment outcome of an individual toward behavior. Ajzen and Fishbein (1980) proposed the most adapted definition of attitude. They refer to attitude as "person's belief and evaluation towards a behavior". Attitude might be favorable or unfavorable, positive or negative, like or dislike (Fang, 2017; Tweneboah-Koduah et al., 2019; Ibnou-laaroussi and Rjoub, 2020). Attitude is categorized in two type namely general attitude and specific attitude. Ibnoulaaroussi and Rjoub (2020), distinguished that general attitude broaden to one's perception toward environmental while specific attitude is the specific perception of an individual such as attitude toward recycling. In this context, author conceptualized general attitude toward environment or environmental attitude to refer one's perception on the environment.

Several studies related to sustainable behavior established that attitude is a best predictor of intention behavior (Cheung and Fok, 2014; Wang et al., 2018; Pan et al., 2018; Liu et al., 2020; Patwary et al., 2020). Previous literature outlines a positive relationship between attitude and intention behavior. Dixit and Badgaiyan (2016) demonstrated that positive attitude encourage individual to support sustainable behavior such as recycling and reuse. Further, Hu et al. (2018) asserted that environmental attitude strengthen the likelihood of an individual to engage in sustainable behavior (recycling behavior).

These evidences are in the same line with the empirical findings of Line and Hanks (2016), Patwary et al. (2020), and Melbye et al. (2017) argued that environmental attitude is positively associated with intention. Further, positive attitude of individual can predict their intention to engage in pro-environmental way (Arrow et al., 2017; Chen and Jai, 2018). Tourists who are more favorable with environment of the destination are more likely they will be engaged in environmentally responsible manner (Wang et al., 2019). Recent study by Khan et al., (2019) followed by Kumar (2019), supported these evidence and concluded that when individuals have a positive perception on the environment they would intend to minimize the negative impact of their behavior on environment. Similarly with findings of Wang et al., (2020) on the study examining pro-environmental behavior among tourists in Zhongshan. In another word, if the degree of positive attitude toward environment increased, the more likely a tourist intends to reduce the environment impact through recycling.

Given these evidence, this study argued that environmental attitude foster young tourist ERBI (recycling intention).

Hypothesis 1: Environmental attitude has a positive influence on younger tourist ERBI

Subjective Norm and Tourist Environmentally Responsible Intention Behavior

Subjective norm refers to the pressure from the social which pushes ones' weather to perform a behavior or not. The 
pressure might come from family members, friends, peers or/and anyone around you who can influence you to act in certain manner or not (Ajzen, 1991). Several scholars urged that environmentally responsible intention of an individual can be predicted with the degree of their social pressure (Khan et al., 2019; Kumar, 2019; Nguyen et al., 2017; Pikturnienè and Bäumle, 2016; Tweneboah-Koduah et al., 2019). Studies show a positive link between subjective norm and intention behavior (Fang, 2017). Hu et al., (2018) proposed that subjective norm is one of the elements that shapes our intention behavior. Suggested by Khan et al., (2019) that increasing the social pressure toward individual they would incline their intention toward pro-environmental behavior. Further, Kumar (2019) asserted that strengthening the social pressures would foster the behavioral intention of individual to support environmentally responsible behavior. Prentice et al. (2019), Wang et al. (2019) and Wang et al. (2019) supported these past findings with the investigation related to TERIB. However, in anticipation to this argument Pikturnienè and Bäumle (2016), Tweneboah-Koduah et al., (2019) and Liu et al., (2020) argued that increasing the subjective norm does not incline the intention of individual to engage in environmentally responsible behavior.

Given to these evidence, this study argued that stronger the social pressure on the younger tourist the more likely they intend to recycle.

Hypothesis 2: Subjective norm has a positive influence on younger tourist ERBI.

\section{Perceived Behavior Control and Tourist environmentally Responsible Intention Behavior}

Perceive behavior control refers to "Self-efficacy and perceived controllability are the two factors that are associated with behavioral performance" (Ajzen, 1991). Numerous scholars on sustainable behavior considered this construct as a crucial determinant of intention behavior. Previous study illustrated that perceived behavior control is positively related to intention (Hu et al., 2018; Kumar, 2019). In other words, willingness to perform in certain behavior can be explained by the ability of an individuals to control of their action when perform in certain manner. Wang et al., (2019) indicated if individuals possess a higher control of their behavior they intend to perform that behavior. Although, this evidence shows the positive influence of perceived behavior control on intention toward environmentally responsible behavior, these findings are inconsistent to Pikturnienè and Bäumle (2016) and Tweneboah-Koduah et al. (2019). Furthermore, Khan et al. (2019) and Liu et al. (2020) also outlines that perceived behavior control is not associated with intention toward pro-environmental behavior.

Therefore, based on previous argument we assumed that the stronger the young tourist's ability to control on their behavior the higher their intention to engage in recycling.

Hypothesis 3: Perceived behavior control has a positive influence on younger tourist ERBI.

\section{Destination Green Image and Tourist Environmentally Responsible Intention Behavior}

Destination image is a subjective construct (Iyer and Reczek, 2017). Destination image define as the physical characteristic, attribute and appearance of the tourist destination that visitors perceived on the destination (Chui et al., 2013). Hahm et al., (2018) refers destination image to the visitor perception about the destination. It has been discussed in the literature of tourist pro-environmental behavior. Green destination image is one of the factor affecting perception and behavior (Cheng et al., 2018). Destination green image refers to the tourist perception on the green attributes of the destination area.

Past empirical tourism research investigated the influence of destination green image on tourist perception (Cheng and Lu, 2013), satisfaction (Bui and Le, 2016) and behavior (Line and Hanks, 2016). Line and Hanks (2016) revealed that destination image is associated to environmentally responsible behavior. Abdullah et al., (2019) proposed that destination green image would be associated with pro-environmental behavior. Previous literature have demonstrated the potential effect of destination green image in inclining intention toward pro-environmental behavior. Carballo and Carmelo (2017), Hahm et al., (2018), and Chen et al., (2018) raveled that destination green image have a positive influence on intention behavior. However, this link is seemingly mediated by attitude; Cheng and Lu, (2013) and Hahm et al., (2018) suggested that positive perception toward the environment of destination area is enhanced by the green destination image. When tourist perceived and believe that the particular destination is aware about the environmental issues, the higher their intention to behave accordingly. In other words, destination green image positively shape the young tourist ERBI.

Therefore, this study suggested that the higher the green image the higher the environmental attitude that leads to higher TERIB.

Hypothesis 4: Destination green image has a positive influence on environmental attitude.

\section{MATERIALS AND METHODS}

The model was tested with Data gathered from 229 younger tourists. Survey was conducted in Bali Island, Indonesia (tourist destination area) to investigate the ERIB of younger tourists. Self-administrated questionnaires were used to collect the information using convenience sampling method. The questionnaire consists of three sections: the first part consists of a short introduction about the research topic and instruction about the questionnaire. The second section consists of the demographic in order to gain more information about the participant characteristic including: Gender, Age, Education, Profession, Religion and so on. The third part consists of the questions for each construct: each construct comprised items adopted from prior research which have been well established and validated in various context. Since, the research objective is to identify the ERIB among young travelers. This study targeted individuals between 18 years old and 26 years old (He et al., 2018) who visit Bali Island, Indonesia for tourist purpose. Respondents must require to acquire a general knowledge about research topic. The usable data collated from the survey were processed and analyzed with the help of SPSS23 and 
eViews10, linear regression were conducted to statistically analyze and test the model. Measurement model evaluation will be conducted including reliability, validity and assumption classic. All the construct was adapted from previous literature and measured through a self-reported using seven-point likert scale ranging from 1 (strongly agree) to 7 (strongly disagree) (Ciocirlan et al., 2020). All the items used to measure each construct were borrowed and modified from previous literatures (Table 2). Tourist behavior intention to reduce waste (recycling and Reuse) was measured with five items adopted from Ajzen (2002), Chu and Chiu (2003), and Lizin et al. (2017). Environmental attitude was conceptualized with four items borrowed from Lee and Jan (2015) and Janmaimool and Khajohnmanee (2019). Subjective norm was measured with four items borrowed from Ajzen (2002), Kumar (2019); Nguyen et al. (2017), Pikturnienè and Bäumle (2016). Perceived behavior control was measured with two items adapted from Kumar (2019), and Pikturnienè and Bäumle (2016). Destination green image was operationalized with four items adapted from Han et al. (2018).

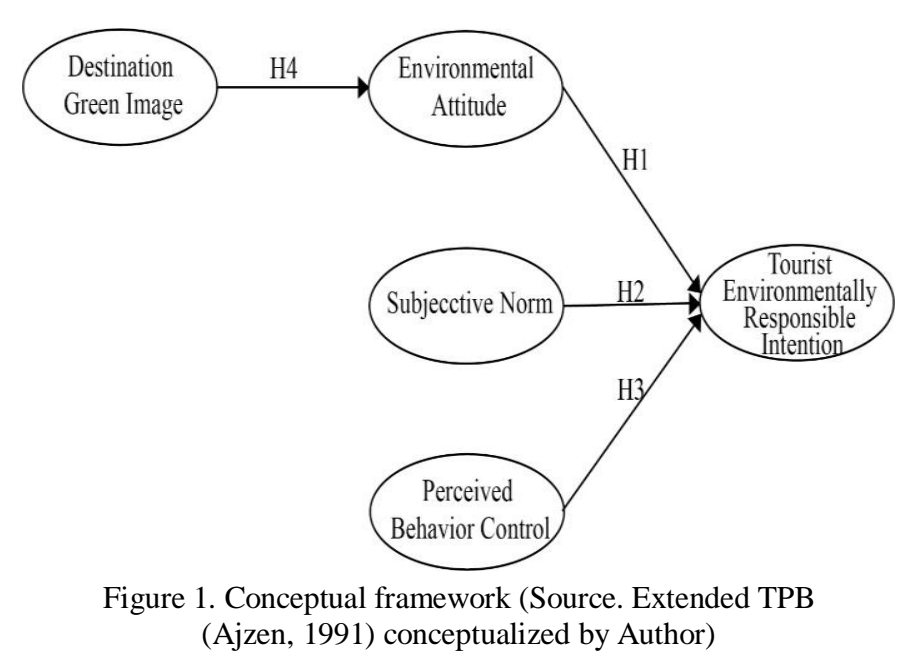

Table 1. Sample Characteristic

\begin{tabular}{|l|c|c|l|c|c|}
\hline Gender & $\mathbf{N}$ & $\mathbf{\%}$ & Level of Education & $\mathbf{N}$ & $\mathbf{\%}$ \\
\hline Female & 147 & 64.2 & Secondary School & 21 & 9.2 \\
\hline Male & 82 & 35.8 & Sophomore & 42 & 18.3 \\
\hline Total & 229 & 100 & Bachelor degree & 115 & 50.2 \\
\hline & & & Master degree & 46 & 20.1 \\
\hline Age & $\mathbf{N}$ & $\mathbf{\%}$ & Others & 5 & 2.2 \\
\hline $18-20$ & 15 & 6.6 & & & \\
\hline $21-23$ & 75 & 32.8 & Occupation & $\mathbf{N}$ & $\mathbf{\%}$ \\
\hline $24-26$ & 139 & 60.7 & Student & 134 & 56.5 \\
\hline & & & Government & 18 & 7.7 \\
\hline Length of Stay & $\mathbf{N}$ & $\mathbf{\%}$ & Private sector & 29 & 9.3 \\
\hline Less than 2 Weeks & 66 & 28 & Entrepreneur & 39 & 18.5 \\
\hline 2 Weeks- 1 month & 162 & 70.7 & Unemployed & 11 & 4.8 \\
\hline More than 1 month & 1 & 4 & Others & 8 & 4.4 \\
\hline
\end{tabular}

\section{Sample characteristics}

Table 1 represents sample characteristics of the 229 respondents in this study. The sample consists of $82(35.8 \%)$ male and $147(64.2 \%)$ female. The sample age ranged as follows: $18-20$ present $6.6 \%, 21-23$ present 32.8\%, $24-26$ present $60.7 \%$. Participants having finished secondary school were 21 (9.2\%), finished sophomore $42(18.3), 115$ (50.2) have a bachelor degree and 46 (20.4) hold a master degree, other $5(2.2 \%)$. The length of stay of the majority of the tourist in Bali island between 2 weeks to 1 month $162(7.7 \%)$.

Reliability and validity were assessed to determine the consistency and accuracy of 5 variables and 19 items used in this study (Hair, 2014) see Table 1. The result of the KMO and Bartlett's test (KMO score $=0.940$, chi-square $=29976.353$, $\mathrm{df}=190, p=0.000$ ) and the Chronbach'Alpha score of the 18 indicators were 0.920. Thus, this indicated that the measure used were reliable as the Chronbach's Alpha score meets the criteria by Sekaran and Bougie, (2016) which required to be above 0.7. Further, the loading factors of each indicators were ranged from $\mathrm{PBC}=0.554$, ATT $=0.933$, DGI $=0.881, \mathrm{SN}=0.621$ and TERIB $=0.898$. The loading factors of each indicators met the requirement above 0.40 by Hair et al (2014).

Table 2. Reliability and validity test

\begin{tabular}{|c|c|c|c|c|}
\hline Constructs & Items & $\begin{array}{l}\text { Construct } \\
\text { Retained } \\
\end{array}$ & $\begin{array}{l}\text { Factor } \\
\text { loading }\end{array}$ & \begin{tabular}{|c|c|}
$\begin{array}{c}\text { Cronbach' } \\
\text { Alpha }\end{array}$ \\
\end{tabular} \\
\hline $\begin{array}{l}\text { Destination } \\
\text { green image }\end{array}$ & $\begin{array}{l}\text { - "In general, the destination has a fine environmental reputation in the minds of its visitors". } \\
\text { - "The tourist destination has a clean and natural environment". } \\
\text { - "The tourist destination has an exotic natural atmosphere". } \\
\text { - "I think that the tourist destination has a strong eco-friendly activities". }\end{array}$ & $\begin{array}{l}\text {-DGI1 } \\
\text {-DGI2 } \\
\text {-DGI3 } \\
\text {-DGI4 }\end{array}$ & $\begin{array}{l}0.619 \\
0.793 \\
0.625 \\
0.822\end{array}$ & 0.881 \\
\hline $\begin{array}{l}\text { Subjective } \\
\text { norm }\end{array}$ & $\begin{array}{l}\text {-"My friends would approve of me performing recycling". } \\
\text { - "Most people who are important to me think that I should recycle". } \\
\text { - "My government expect me to minimize my waste". }\end{array}$ & $\begin{array}{l}-\mathrm{SN} 1 \\
-\mathrm{SN} 2 \\
-\mathrm{SN} 3\end{array}$ & $\begin{array}{l}0.435 \\
0.569 \\
0.710\end{array}$ & 0.621 \\
\hline $\begin{array}{l}\text { Perceived } \\
\text { behavior control }\end{array}$ & $\begin{array}{l}\text { - "If I wanted to, I would not have problems in succeeding to recycle my waste". } \\
\text { - "I have full control over recycling my waste". }\end{array}$ & $\begin{array}{l}-\mathrm{PBC} 1 \\
-\mathrm{PBC} 2\end{array}$ & $\begin{array}{l}0.557 \\
0.744\end{array}$ & 0.554 \\
\hline $\begin{array}{l}\text { Environmental } \\
\text { attitude }\end{array}$ & $\begin{array}{l}\text {-"We are approaching the limit of the number of people the earth can support". } \\
\text {-"Humans have the right to modify the natural environment to suit their needs". } \\
\text {-"The balance of nature is very delicate and easily upset". } \\
\text {-"The earth is like a spaceship with very limited room and resources". }\end{array}$ & $\begin{array}{l}\text {-ATT1 } \\
\text {-ATT2 } \\
\text {-ATT3 } \\
\text {-ATT4 }\end{array}$ & $\begin{array}{l}0.840 \\
0.842 \\
0.883 \\
0.829\end{array}$ & 0.933 \\
\hline $\begin{array}{l}\text { Intention to } \\
\text { recycle }\end{array}$ & $\begin{array}{l}\text {-"I plan to make plans to engage in recycle regularly during my traveling" } \\
\text {-"I am willing to engage in environmentally responsible behavior when traveling" } \\
\text {-"I intend to recycle my waste". } \\
\text {-"I probably support recycling to reduce the negative impact of trip to the environment". } \\
\text {-"I will engage in environmentally responsible way such as recycling during my visit". }\end{array}$ & $\begin{array}{l}\text {-TERIB } \\
\text {-TERIB } \\
\text {-TERIB } \\
\text {-TERIB } \\
\text {-TERIB }\end{array}$ & $\begin{array}{l}.779 \\
.802 \\
.755 \\
.733 \\
.802\end{array}$ & .898 \\
\hline
\end{tabular}




\section{Assumption classic}

Breusch-Godfrey Serial Correlation LM Test assessed to identify the auto correlation problematic. The result shows $(\mathrm{F}=$ $0.221, \mathrm{R} 2=0.456, p . \mathrm{F}=0.801, p$ Chi-square $=0.796$ ) the $p$. chi-square is $>0.05$, means that the model is autocorrelation problematic free. VIF was demonstrated to identify the multicollinearity problematic. Table 3 shows that that the VIF of each constructs are between 0.1 and 10 indicated that there was no mutlicolinearity found. Further, heteroskedasticity ARCH test issue were identify the heteroskedasticity problem. The $\mathrm{P}$ chi-square required to be greater that the significant level. The result $\left(\mathrm{F}=1906, \mathrm{R}^{2}=9,235, p \mathrm{~F}(1,211)=0.099, p\right.$ Chi-square $\left.=0.100\right)$ indicated that there is no heteroskedasticity problem found. Table 4 shows the correlation of TPB and destination image to identify the correlations, the table shows that each correlation were significant and did not exceeded 0.8 (Akoglu, 2018).

Table 3. Variance Inflation Factors

\begin{tabular}{|c|c|c|c|}
\hline & Coefficient & Uncentered & Centered \\
\hline Variable & Variance & VIF & VIF \\
\hline C & 0.067 & 52.476 & NA \\
\hline ATT & 0.003 & 95.025 & 2.116 \\
\hline SN & 0.001 & 50.964 & 1.730 \\
\hline PBC & 0.001 & 31.671 & 1.304 \\
\hline DGI & 0.001 & 25.769 & 1.248 \\
\hline
\end{tabular}

Table 5. Regression analysis

\begin{tabular}{|c|c|c|c|c|c|}
\hline & Variable & $\boldsymbol{\beta}$ & S.E & t & p-value \\
\hline & C & 0.696 & 0.259 & 2.686 & 0.007 \\
\hline H1 & ATT $>$ INT & 0.644 & 0.055 & 11.556 & $* * *$ \\
\hline H2 & SN $>$ INT & 0.219 & 0.044 & 4.944 & $* * *$ \\
\hline H3 & PBC $>$ INT & 0.000 & 0.033 & 0.008 & 0.993 \\
\hline H4 & DGI $>$ ATT & 0.340 & 0.045 & 7.490 & $* * *$ \\
\hline
\end{tabular}

Note: Significant level $*<0.05, * *<0.01, * * *<0.001$
Table 4. Correlation of TPB and destination Image

\begin{tabular}{|c|c|c|c|c|c|}
\hline & ATT & DGI & PBC & INT & SN \\
\hline ATT & 1 & & & & \\
\hline DGI & $\begin{array}{c}0.445 \\
* * *\end{array}$ & 1 & & & \\
\hline PBC & $\begin{array}{c}0.471 \\
* * *\end{array}$ & $\begin{array}{c}0.234 \\
* * *\end{array}$ & 1 & 1 & 1 \\
\hline INT & $\begin{array}{c}0.802 \\
* * *\end{array}$ & $\begin{array}{c}0.375 \\
* * *\end{array}$ & $\begin{array}{c}0.398 \\
* * *\end{array}$ & 1 \\
\hline SN & $\begin{array}{c}0.643 \\
* * *\end{array}$ & $\begin{array}{c}0.304 \\
* * *\end{array}$ & $\begin{array}{c}0.381 \\
* * *\end{array}$ & $\begin{array}{c}0.660 \\
* * *\end{array}$ & 1 \\
\hline
\end{tabular}

Note: Significant level $* * *<0.001$

ATT: Attitude, DGI: Destination green Image, PBC: Perceived behavior control, SN: Subjective norm, INT: Intention

\section{RESULTS AND DISCUSSION}

The regression analysis was conducted to confirm the proposed model Table 5. The model is relatively good with $\mathrm{R}^{2}$ (0.679), Adjusted $\mathrm{R}^{2}=0.673$, S.E. of regression $=0.541$, F-statistic 118.726 ) with $\mathrm{p}(\mathrm{F}$-statistic) $<.000$. The $67 \%$ the variance in TERB is explained with the model.

The regression analysis shows a significant positive influence of environmental attitude on intention (H1) with ( $\beta$ : 0.644 , S.E: 0.055; t-statistic: 7.490), and a p-value 0.000 which is $<0.001$ significant level. Thus, the finding supported the H2. The hypothesis $\mathrm{H} 2$ suggested that subjective norms have a positive influence on environmentally responsible intention behavior (ERIB). The regression result supported the hypothesis with $(\beta: 0.219$, S.E: 0.044 ; $\mathrm{t}$-statistic: 4.944$)$, and a p-value $0.000<$ 0.001 significant level. Thus, H2 was supported. The hypothesis H3 posits that perceived behavior control has a positive influence on ERIB. The Table demonstrated ( $\beta$ : 0.000 , S.E: 0.033 ; t-statistic: 0.008 ), and a p-value 0.993 greater that the significant level. Therefore, the statistical result did not support the hypothesis H3. Hypothesis $\mathrm{H} 4$ determined the positive influence of destination green image on ERIB. The result statistically showed a ( $\beta$ : 0.340 , S.E: 0.045 ; t-statistic: 7.490$)$, and a p-value 0.000 which is $<0.001$ significant level. The finding supported the proposed hypothesis H4.

Previous study suggested that the TPB elements (attitude, Subjective norm, Perceived behavior control) are the primary antecedent of intention behavior (White and Simpson, 2013; Ham et al., 2015; Hu et al., 2018). Few studies have proposed the importance of destination image on the model (Wang et al., 2020). The construct integrated in model explained the $67 \%$ of the variance of ERIB, the rest can be explained with different factors which is not considered in this study. This study shows that destination is related to environmental attitude that relationship can enhance intention behavior of tourist. Similarly to past study Ashraf et al. (2019), tourist judgment of the environment determined by their perception of the destination. Tourist would be more favorable with a destination that is considered to be green, destination that have environmental activity related. The green perception that tourist have toward tourist destination area the more they display a positive attitude toward the surrounding environment. Further, positive effect of influence of environmental attitude and subjective norm on ERIB also were found. The findings are consistent with the prior study by Cheng and Lu (2013), Cheng et al. (2018), and Hahm et al. (2018) in which they highlighted the positive impact of these two TPB constructs (attitude and subjective norm) on intention to behave in environmentally friendly when traveling. This work validated the proposed hypothesis that environmental attitude explained intention toward ERB. This finding is in the same line with past empirical study findings Hu el al. (2018) Line and Hanks (2016), Melbye et al., (2017) Arrow et al., (2017), and Wang et al., (2020). When younger tourists have higher positive attitude toward the environment tourist destination they would behave more environmentally friendly and engaged environmentally responsible way reduce their environmental footprint. They are willing to engage sustainable behavior such as recycling. Thus, this noted that younger tourists considered environmental attitude in respect of ERIB.

The respondents of this study considered the social pressure as driven force of their behavior. This finding supported the previous findings of $\mathrm{Hu}$ et al., (2018), Khan et al., (2019), Kumar (2019), and Wang et al., (2020) in which they argued that subjective norm determined intention behavior toward ERB when traveling. This work confirmed that the stronger the social pressure toward an individual to engage in environmental way the more likely they are willing to behave accordingly. Albeit, traveling away from home tied with the idea of seeking a personal freedom, going away from daily life and habit (Xu et al., 
2020). Younger tourists are still tight with their social norm, their intention to support ERB is determined by what social expected them to do. Surprisingly, our findings did not supported the link between perceived behavior control and TERIB. The result shows an insignificant link between perceived behavior control and TERIB. In reference to Pikturnienè and Bäumle, (2016) and Tweneboah-Koduah et al., (2019), Khan et al., (2019), Liu et al., (2020), and Wang et al., (2020) have shown that perceived behavior control does not influence intention toward ERB. This result revealed that the younger tourists did not considered this factor as an antecedent of their intended behavior toward ERB. In other words, they intended to behave in environmental way regardless their ability to take control over behavior.

Hypothesis H1, H2 were confirmed, attitude and subjective norm have positive influence on younger tourists' intention behavior toward ERB. This adds to the literature of ERB in context of younger tourist behavior more specifically in recycling when traveling. Further, the result rejected the H3, although the past study and TPB proposed the idea that this variable is considered to determine intention behavior. This empirical work did not validate the model on (positive influence of perceived behavior control on ERIB). However, few prior study have demonstrated a similar finding with the present study. Furthermore, integrating destination green image increased the variance of the initial TPB model. This research, demonstrated the importance of destination image in the theory of planned behavior in explaining the ERIB in context of younger tourist.

\section{CONCLUSION}

The aim of this study is to explain the TERIB by integrating destination image in TPB. The study focused on younger tourist intention to engage in recycling when traveling. The result of this study contributes to the extent of theory of planned behavior in context of ERB. Also, the results showed that younger tourists are attached with their social norm when traveling. They will behave appropriately to the expectations of the people who are important to them. Positive attitude toward the environment encourage younger tourist to minimize the negative environmental impact of their behavior when traveling. The findings also highlight the importance of destination image in shaping sustainable behavior.

Tourist visiting destination that with green activities and have some green attribute are more likely to support the ecofriendly or green manner necessary to protect the environment of the destination. Further, this revealed that perceived behavior control does not reinforce tourist intention to participate in recycling. This study provides a theoretical and practical contribution. Environmental attitude found to be the one of the important factor to be considered in TPB, particularly in TERIB. The current research found that there is a potential contribution of destination green image on TPB. Destination green expressed favorable attitude toward the environmental. This findings contribute to the theory that destination green image plays an important role in theory of planned behavior, it might influence the intention toward environmentally responsible behavior through environmental attitude. Although, the green image of the destination contribute to the TPB, there are some internal factors that future research should be considered that influence the TERIB such as value, knowledge and emotion. For practical implication, tourist destination are encouraged to introduce green environmental practices and provide such eco-friendly activities. Ecotourism and green tourism activities would promote environmental friendly behavior. Based on the findings, tourists are more likely to behave in sustainable manner in destination that they promote green practices. Thus, destination management are encouraged to introduce eco-friendly and/or sustainable activities related to younger tourists. Further, tourist destination also recommended to leverage social norm as it can motivate individual to reduce their environmental footprint when traveling.

Local community are encouraged to set norm that encourage tourists and visitors to support the environmental protection in destination. To illustrate, local community in the tourist destination should promote recycling. The result of this study is not only to propose to improve tourist's environmental behavior but also give an understanding on the significant role that destination itself play in enriching such a behavior. Notwithstanding, there are few limitation that need to be taken into account in this study. Although this study focused on younger tourist behavior, the sample was limited to younger respondents (18-26 year old) which cannot represent the younger generation as a whole. This study was conducted in Bali Island Indonesia, so the result is limited to younger visitors who visited the Island. We recommend future researchers to implement and measure the model in different settings, cross-cultural studies are highly recommended to provide a broader knowledge. Comparison study between domestic visitor and international also should be taken into account. The study was conducted in limited time period, further study should conduct longitudinal studies to provide better understanding on the changes over time. The method implied in this study did not give an explicit result.

\section{REFERENCES}

Abdullah, S.I.N.W., Samdin, Z., Teng, P.K., \& Heng, B.L.J. (2019). The impact of knowledge, attitude, consumption values and destination image on tourists' responsible environmental behaviour intention. Management Science Letters, 9(9), 1461-1476. https://doi.org/10.5267/j.msl.2019.5.005

Akoglu, H. (2018). User's guide to correlation coefficients. Turkish Journal of Emergency Medicine, 18(3), 91-93. https://doi.org/10. 1016/j.tjem.2018.08.001

Ajzen, I. (1991). The Theory of Planned Behavior. Organizational Behavior and Human Decision Processes, 50(2), $179-211$. https://doi.org/10.1016/0749-5978(91)90020-T

Arbulu, I., Lozano, J., \& Rey-Maquieira, J. (2017). Waste generation flows and tourism growth: A STIRPAT Model for Mallorca. Journal of Industrial Ecology, 21(2), 272-281. https://doi.org/10.1111/jiec.12420

Arrow, K., Dasgupta, P., Goulder, L., Daily, G., Ehrlich, P., Heal, G., Levin, S., Mäler, K.G., Schneider, S., Starrett, D., \& Walker, B. (2017). Are we consuming too much? Sustainability, 18(3), 357-382. https://doi.org/10.4324/9781315241951-32

Ashraf, M.S., Ashraf, R.U., Kim, W.G., \& Ahmad, W. (2019). Modeling tourists' visiting intentions toward ecofriendly destinations : Implications for sustainable tourism operators. Business Strategy and the Environment. 29(1), 54-71. https://doi.org/10.1002/bse.2350

Biswas, A., Licata, J.W., McKee, D., Pullig, C., \& Daughtridge, C. (2000). The recycling cycle: An empirical examination of consumer waste recycling and recycling shopping behaviors. Journal of Public Policy and Marketing, 19(1), 93-105. https://doi.org/10.1509/jppm.19.1.93.16950 
Budeanu, A. (2007). Sustainable tourist behaviour - a discussion of opportunities for change. International Journal of Consumer Studies, 31(5), 499-508. https://doi.org/10.1111/j.1470-6431.2007.00606.x

Bui, H.T., \& Le, T.A. (2016). Tourist satisfaction and destination image of Vietnam's Ha Long Bay. Asia Pacific Journal of Tourism Research, 21(7), 795-810. https://doi.org/10.1080/10941665.2015.1075564

Carballo, R.F., \& Carmelo, J.L. (2017). The influence of artistically recreated nature on the image of tourist destinations: Lanzarote's art, cultural and tourism visitor centres and their links to sustainable tourism marketing. Journal of Sustainable Tourism, 26(2), 192-204. https://doi.org/10.1080/09669582.2017.1338292

Ciocirlan, C.E., Gregory-Smith, D., Manika, D., \& Wells, V. (2020). Using Values, Beliefs, and Norms to Predict Conserving Behaviors in Organizations. European Management Review, 17(2), 543-558. https://doi.org/10.1111/emre.12388

Chen, F., Chen, H., Yang, J., Long, R., \& Li, Q. (2018). Impact of information intervention on the recycling behavior of individuals with different value orientations-An experimental study on express delivery packaging waste. Sustainability, 10(10), 3617. https://doi.org/10.3390/su10103617

Cheng, T.M., \& Lu, C.C. (2013). Destination Image, Novelty, Hedonics, Perceived Value, and Revisiting Behavioral Intention for Island Tourism. Asia Pacific Journal of Tourism Research, 18(7), 766-783, https://doi.org/10.1080/10941665.2012.697906

Cheng, T.M., \& Wu, H.C. (2015). How do environmental knowledge, environmental sensitivity, and place attachment affect environmentally responsible behavior? An integrated approach for sustainable island tourism. Journal of Sustainable Tourism, 23(4), 557-576. https://doi.org/10.1080/09669582.2014.965177

Cheung, L.T.O., \& Fok, L. (2014). Assessing the Role of Ecotourism Training in Changing Participants' Pro-Environmental Knowledge, Attitude and Behaviour. Asia Pacific Journal of Tourism Research, 19(6), 645-661. https://doi.org/10.1080/10941665.2013.797003

Chia, S.K.S., Lo, M.C., Razak, Z.B., Wang, Y.C., \& Mohamad, A.A. (2021). Impact of destination image on tourist satisfaction: the moderating effect of Information Technology (IT). GeoJournal of Tourism and Geosites, 34(1), 88-93. https://doi.org/10.30892/gtg.34112-623

Chu, P.Y., \& Chiu, J.F.,(2003). Factors influencing household waste recycling behavior: test of an integrated model. J. Appl. Soc. Psychol. 33 (3), 604-626. https://doi.org/10.1111/j.1559-1816.2003.tb01915.x

Chui, C. B. T., Khanb, N. R. M., \& Rahim, F, H. A. (2013). Understanding Cultural Heritage Visitor Behavior: The Case of Melaka as World Heritage City. Procedia - Social and Behavioral Sciences. 130 (2014), 1-10. https://doi.org/10.1016/j.sbspro.2014.04.001

Clark, E., Mulgrew, K., Kannis-Dymand, L., Schaffer, V., \& Hoberg, R. (2019). Theory of Panned Behaviour: predicting tourists' pro-environmental intentions after a humpback whale encounter. Journal of Sustainable Tourism. 27(5), 649-667. https://doi.org/10.1080/09669582.2019.1603237

Dixit, S., \& Badgaiyan, A.J. (2016). Towards Improved Understanding of Reverse Logistics - Examining Mediating Role of Return Intention. Resources, Conservation and Recycling, 107(2016), 15-28. http://dx.doi.org/10.1016/j.resconrec.2015.11.021

Fang, W. (2017). Normative Beliefs, Attitudes, and Social Norms: People Reduce Waste as an Index of Social Relationships When Spending Leisure Time. Sustainability, 9(10), 1696. https://doi.org/10.3390/su9101696

Hair, J., Joseph, F., Black, W.C., Barr, J., \& Anderson, B.R.E. (2014). Multivariate Data Analysis, Seventh Edition

Hahm, J., Tasci, A.D., \& Terry, D.B. (2018). Investigating the interplay among the Olympic Games image, destination image, and country image for four previous hosts. Journal of Travel and Tourism Marketing, 35(6), 755-771. https://doi.org/10.1080/10548408.2017.1421116

Ham, M., Jeger, M., \& Ivković, A.F. (2015). The role of subjective norms in forming the intention to purchase green food. Economic Research-Ekonomska Istrazivanja, 28(1), 738-748. https://doi.org/10.1080/1331677X.2015.1083875

Han, H., Yu, J., \& Kim, W. (2018). Youth travelers and waste reduction behaviors while traveling to tourist destinations. Journal of Travel and Tourism Marketing, 35(9), 1119-1131. https://doi.org/10.1080/10548408.2018.1435335

Han, J.H., Lee, M.J., \& Hwang, Y.S. (2016). Tourists' environmentally responsible behavior in response to climate change and tourist experiences in nature-based tourism. Sustainability, 8(7), 1-14. https://doi.org/10.3390/su8070644

Han, H., Kim, W., \& Kiatkawsin, K., (2016). Emerging youth tourism: fostering young travelers' conservation intentions. Journal of Travel and Tourism Marketing, 34(7), 905-918. https://doi.org/10.1080/10548408.2016.1261758

He, X., Hu, D., Swanson, S.R., Su, L., \& Chen, X. (2018). Destination perceptions, relationship quality, and tourist environmentally responsible behavior. Tourism Management Perspectives, 28(October), 93-104. https://doi.org/10.1016/j.tmp.2018.08.001

Hu, H., Zhang, J., Chu, G., Yang, J., \& Yu, P. (2018). Factors influencing tourists' litter management behavior in mountainous tourism areas in China. Waste Management, 79, 273-286. https://doi.org/10.1016/j.wasman.2018.07.047

Ibnou-laaroussi, S., \& Rjoub, H. (2020). Sustainability of Green Tourism among International Tourists and Its Influence on the Achievement of Green Environment : Evidence from North Cyprus. Sustainability, 12(14), 5698; https://doi.org/10.3390/su121456981-24

Iyer, E.S., \& Reczek, R.W. (2017). The intersection of sustainability, marketing, and public policy: Introduction to the special section on sustainability. Journal of Public Policy and Marketing, 36(2), 246-254. https://doi.org/10.1509/jppm.36.250

Janmaimool, P., \& Khajohnmanee, S. (2019). Roles of environmental system knowledge in promoting university students' environmental attitudes and pro-environmental behaviors. Sustainability, 11(16). https://doi.org/10.3390/su11164270

Khan, F., Ahmed, W., \& Najmi, A. (2019). Understanding consumers' behavior intentions towards dealing with the plastic waste: Perspective of a developing country. Resources, Conservation and Recycling, 142(November), 49-58. https://doi.org/10.1016/j.resconrec.2018.11.020

Kiatkawsin, K., \& Han, H. (2017). Young travelers' intention to behave pro-environmentally : Merging the value-belief-norm theory and the expectancy theory. Tourism Management, 59, 76-88. https://doi.org/10.1016/j.tourman.2016.06.018

Kiatkawsin, K., Sutherland, I., \& Lee, S.K. (2020). Determinants of Smart Tourist Environmentally Responsible Behavior Using an Extended Norm-Activation Model. Sustainability, 12(12). https://doi.org/10.3390/su12124934

Kim, M.S., \& Stepchenkova, S. (2019). Altruistic values and environmental knowledge as triggers of pro-environmental behavior among tourists. Current Issues in Tourism, 23(13), 1575-1580. https://doi.org/10.1080/13683500.2019.1628188

Kim, M.S., Thapa, B., \& Kim, H. (2017). International tourists' perceived sustainability of Jeju Island, South Korea. Sustainability, 10(1), 113. https://doi.org/10.3390/su10010073

Kumar, A. (2019). Exploring young adults' e-waste recycling behaviour using an extended Theory of Planned Behaviour model: A crosscultural study. Resources, Conservation and Recycling, 141(February), 378-389. https://doi.org/10.1016/j.resconrec.2018.10.013

Landon, A.C., Woosnam, K.M., \& Boley, B.B. (2018). Modeling the psychological antecedents to tourists' pro-sustainable behaviors: an application of the value-belief-norm model. Journal of Sustainable Tourism, 26(6), 957-972. https://doi.org/10.1080/09669582.2017.1423320

Lee, T.H., \& Jan, F.H. (2015). The influence of recreation experience and environmental attitude on the environmentally responsible behavior of community-based tourists in Taiwan. Journal of Sustainable Tourism, 23(7), 1063-1094. https://doi.org/10.1080/09669582.2015.1032298 
Line, N.D., \& Hanks, L. (2016). The effects of environmental and luxury beliefs on intention to patronize green hotels: the moderating effect of destination image. Journal of Sustainable Tourism, 24(6), 904-925. https://doi.org/10.1080/09669582.2015.1091467

Liu, A., Ma, E., Qu, H., \& Ryan, B. (2020). Daily green behavior as an antecedent and a moderator for visitors' pro-environmental behaviors. Journal of Sustainable Tourism, 28(9), 1390-1408. https://doi.org/10.1080/09669582.2020.1741598

Lizin, S., Van Dael, M., \& Van Passel, S. (2017). Battery pack recycling: Behaviour change interventions derived from an integrative theory of planned behaviour study. Resources, Conservation and Recycling, 122(July), 66-82. https://doi.org/10.1016/j.resconrec.2017.02.003

Melbye, E.L., Onozaka, Y., \& Hansen, H. (2017). Throwing It All Away: Exploring Affluent Consumers' Attitudes Toward Wasting Edible Food. Journal of Food Products Marketing, 23(4), 416-429. https://doi.org/10.1080/10454446.2015.1048017

Najib, M., Sumardi, R.S., Nurlaela, S., \& Fahma, F. (2020). Determinant factors of Muslim Tourist motivation and attitude in Indonesia and Malaysia. GeoJournal of Tourism and Geosites, 31(3), 936-943. https://doi.org/10.30892/gtg.31301-524

Nguyen, T.N., Nguyen, H.V., Lobo, A., \& Dao, T.S. (2017). Encouraging Vietnamese household recycling behavior: Insights and implications. Sustainability, 9(2), 1-15. https://doi.org/10.3390/su9020179

Nindyati, A.D. (2015). Green Behavior (Reuse, Reduce , Recycling -3R ) At Home and At Workplace. The 5th International Asian Association of Indigenous and Cultural Psychology (AAICP). Surakarta, Indoneisa. https://doi.org/10.13140/RG.2.1.3229.7365

Nunkoo, R., Seetanah, B., Rifkha, Z., Jaffur, K., George, P., \& Moraghen, W. (2019). Tourism and Economic Growth : A Meta-regression Analysis. Journal of Travel Research, 59(3). https://doi.org/10.1177/0047287519844833

Pan, S., Chou, J., Morrison, A.M., \& Lin, M. (2018). Will the Future Be Greener? The Environmental Behavioral Intentions of University Tourism Students. Sustainability, 10(3). https://doi.org/10.3390/su10030634

Pan, Y., \& Liu, J.G. (2018). Antecedents for College Students' environmentally responsible behavior: Implications for collective impact and sustainable tourism. Sustainability, 10(6). https://doi.org/10.3390/su10062024

Patwary, A.K., Omar, H., \& Tahir, S. (2021). The Impact of perceived environmental responsibility on Tourist' intention to visit Green Hotel: The Mediating role of attitude. GeoJournal of Tourism and Geosites, 34(1), 9-13. https://doi.org/10.30892/gtg.34101-612

Pikturnienè, I., \& Bäumle, G. (2016). Predictors of recycling behaviour intentions among urban Lithuanian inhabitants. Journal of Business Economics and Management, 17(5), 780-795. https://doi.org/10.3846/16111699.2014.951957

Prentice, C., Chen, J., \& Wang, X. (2019). The influence of product and personal attributes on organic food marketing. Journal of Retailing and Consumer Services, 46(October), 70-78. https://doi.org/10.1016/j.jretconser.2017.10.020

Sekaran, U., \& Bougie, R. (2016). Research methods for business: a skill-building approach. Wiley

Su, L., Hsu, M.K., \& Boostrom, R.E. (2019). From recreation to responsibility : Increasing environmentally responsible behavior in tourism. Journal of Business Research, 109(March), 557-573. https://doi.org/10.1016/j.jbusres.2018.12.055

Tweneboah-Koduah, E.Y., Adams, M., Nyarku, K.M., Yaw, E., Adams, M., \& Nyarku, K.M. (2019). Using Theory in Social Marketing to Predict Waste Disposal Behaviour among Households in Ghana. Journal of African Business, 21(1), 62-77. https://doi.org/10.1080/15228916.2019.1597323

Wang, C., Zhang, J., Cao, J., Hu, H., \& Yu, P. (2019). The influence of environmental background on tourists' environmentally responsible behaviour. Journal of Environmental Management, 231(October), 804-810. https://doi.org/10.1016/j.jenvman.2018.10.089

Wang, C., Zhang, J., Xiao, X., Sun, F., Xiao, M., \& Shi, Q. (2020). Examining the dimensions and mechanisms of tourists' environmental behavior : A Theory of Planned Behavior approach. Journal of Cleaner Production, 273(November), 123007. https://doi.org/10.1016/j.jclepro.2020.123007

Wang, C., Zhang, J., Yu, P., \& Hu, H. (2018). The Theory of Planned Behavior as a model for understanding tourists' responsible environmental behaviors: The moderating role of environmental interpretations. Journal of Cleaner Production, 194(September), 425434. https://doi.org/10.1016/j.jclepro.2018.05.171

Wang, X., Qin, X., \& Zhou, Y. (2019). A comparative study of relative roles and sequences of cognitive and affective attitudes on tourists ' proenvironmental behavioral intention. Journal of Sustainable Tourism, 28(5), 727-746. https://doi.org/10.1080/09669582.2019.1704297

White, K., \& Simpson, B. (2013). When do (and Don't) normative appeals influence sustainable consumer behaviors? Journal of Marketing, 77 (2), 78-95. https://doi.org/10.1509/jm.11.0278

Xu, F., Huang, L., \& Whitmarsh, L. (2020). Home and away : cross-contextual consistency in tourists' pro-environmental behavior. Journal of Sustainable Tourism, 28(10), 1443-1459. https://doi.org/10.1080/09669582.2020.1741596

$\mathrm{Xu}$, Y., Wei, X., \& Chen, S.C. (2019). Determinants and mechanisms of tourists' environmentally responsible behavior: Applying and extending the Value-Identity-Personal norm model in China. Sustainability, 11(13). https://doi.org/10.3390/su11133711

Zhang, H., Zhang, Y., Song, Z., \& Lew, A.A. (2019). Assessment bias of environmental quality (AEQ), consideration of future consequences (CFC), and environmentally responsible behavior (ERB) in tourism. Journal of Sustainable Tourism, 27(5), 609-628. https://doi.org/10.1080/09669582.2019.1597102

Zhang, K., Hou, Y., \& Li, G. (2019a). Tourists and Air Pollution: How and Why Air Pollution Magnifies Tourists' Suspicion of Service Providers. Journal of Travel Research, 59(4) https://doi.org/10.1177/0047287519859710

Zhou, X., Tang, C., Lv, X., \& Xing, B. (2020). Visitor engagement, relationship quality, and environmentally responsible behavior. International Journal of Environmental Research and Public Health, 17(4). https://doi.org/10.3390/ijerph17041151

Zuo, B., \& Huang, S.S. (2019). A Structural Change and Productivity Perspective of Tourism's Contribution to Economic Growth : The Case of Zhangjiajie in China. Journal of Travel Research, 59(3). https://doi.org/10.1177/0047287519841720

Article history: Received: 11.02.2021 Revised: 16.04.2021 Accepted: 14.06.2021 Available online: 30.06 .2021

